\title{
MESIN DISPENSER PAKAN OTOMATIS HEMAT ENERGI
}

Fauzi Ilham $\mathrm{A}^{1,2}$, Nurul Hiron ${ }^{1}$, Nundang Busaeri

Teknik Elektro, Fakultas Teknik, Universitas Siliwangi ${ }^{1}$

Email : ahmadillham.fauzi999@gmail.com²

\begin{abstract}
Feeding is one of the important thing in the case of fish cultivation and harvesting the high population mobility in Indonesian still cannot be matched by the availability of production, nowadays, in general feeding is still depending on direct human help, so that people now just found a new technique to feed fish, runs and operates the tools automatically regarding to time and schedule that is provided or based on operation time of period they wanted and how much they want to feed. With the technology advancement, $i$ would try to create innovating feeding machine with the mechanic system, make the feeding can be programmed and the duration of feeding can be controlled. By way of vertical valve modeling that works when getting an order from arduino UNO, so that once the valve opening with opening anggle $0^{\circ}$ to $45^{\circ}, 0^{\circ}$ to $90^{\circ}, 0^{\circ}$ to $180^{\circ}$ only requires a short duration making the required power more efficient.
\end{abstract}

Keywords: : Arduino Uno, Feeding, Mechanic, Valve

\begin{abstract}
Abstrak
Pemberian pakan merupakan salah satu hal penting untuk usaha budidaya ikan karena tingginya mobilitas penduduk di Indonesia masih belum bisa diimbangi dengan ketersediaan produksinya, akibatnya permintaan semakin banyak dan produksi melambat dari tahun ke tahun. Saat ini pemberian pakan umumnya masih tergantung pada sumber daya manusia yang bersifat manual. Oleh karena itu dirancang alat untuk memberi pakan ikan yang dapat bekerja secara otomatis berdasarkan waktu atau jadwal pemberian pakan dan jumlah atau takaran pakan. Dengan kemajuan teknologi saya mencoba membuat rancang bangun pakan ikan dengan cara rancang bangun mesin pemberi pakan dengan sistem mekanik hemat energi, menjadikan pemberian pakan ikan dapat diprogram dan diatur durasi pemberian pakan ikan. Dengan cara pemodelan valve vertikal yang bekerja ketika mendapat perintah dari arduino UNO, sehingga dalam satu kali bukaan valve dengan sudut bukaan $0^{\circ}$ sampai $45^{\circ}, 0$ sampai $90^{\circ}$ dan $0^{\circ}$ sampai $180^{\circ}$ hanya membutuhkan durasi yang singkat menjadikan daya yang dibutuhkan lebih efisien
\end{abstract}

Kata kunci : Arduino Uno, Mekanik, Pakan ikan, Valve

\section{PENDAHULUAN}

Perekonomian merupakan sektor yang paling vital dalam kehidupan dan juga kelancaran dalam fase pertumbuhan ekonomi di Indonesia. Salah satu masalah yang belum teratasi hingga detik ini adalah masalah kelancaran dalam segi produksi maupun pemasaran. Tingginya mobilitas penduduk di Indonesia masih belum bisa diimbangi dengan ketersediaan produksinya, akibatnya permintaan semakin banyak dan produksi melambat dari tahun ke tahun. Maka dari itu usaha budidaya ikan air tawar semakin hari semakin menggiurkan[1].

Pembuatan dan perancangan Alat Pemberi Pakan Ikan memiliki aspek yang dibutuhkan oleh masyakat, baik dalam hal operasi yang mudah untuk dioprasikan juga memiliki keunggulan dalam hal menghemat energi dapat diakali melalui perancangan yang matang diharapkan pada eksekusinya dapat menghemat dari segi ekonomisnya juga, penambak ikan air tawar menghemat dalam pemberian upah pada pekerja imtinya mengurangi pekerja pemberi pakan yang manual bisa juga untuk pemberian pakan dilakukan oleh penambak saja.

Pada teknik pemberian pakan ikan dengan sistem auto feeding, permasalahan utama dari mesin pemberi pakan adalah teknik akurasi bobot pakan yang diberikan dan penjadwalan pemberian pakan dan penyebaran pakan pada kolam. Pada masalah akurasi bobot, metode yang digunakan dengan cara menggunakan dispenser jenis turbin belimbing dengan putaran horisontal. metode ini memberikan kinerja yang baik, tetapi sayangnya konsumsi energi listrik menjadi tinggi, dikarenakan turbin belimbing selalu berputar selama pakan dipindahkan dari tangki pakan ke dispenser atas kemudian ke unit penimbangan. Pada masalah akurasi pemberikan bobot pakan, saat ini metode belum sesuai pada bobot yang diinginkan. Pada dasarnya pemberian pakan dengan ukuran yang berbeda memiliki estimasi waktu yang berbeda pula, akan tetapi apabila waktu yang dibutuhkan untuk pemberian pakan memiliki akurasi yang yang tinggi makan pakan yang dibutuhkan akan sesuai dengan sistem.

\subsection{ARDUINO UNO}

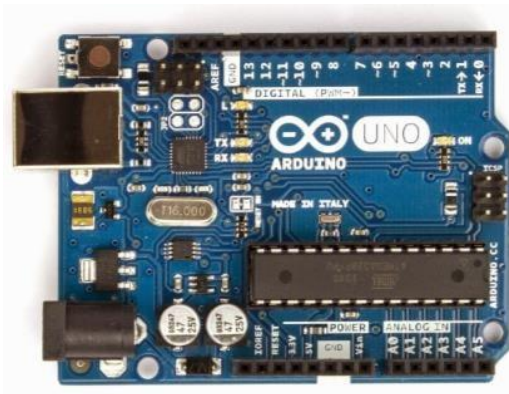

Gambar 1. Arduino Uno Board[2]

Arduino uno merupakan jenis arduino yang paling banyak digunakan. Arduino pada mesin pakan digunakan sebagai controler terhadap load cell untuk mengkontrol bukaan valve terhadap flow pakan. 


\subsection{SERVO MOTOR (LF-20MG)}

Motor servo disusun dari sebuah motor DC, gearbox, variabel resistor (VR) atau potensiometer dan rangkaian kontrol. Potensiometer berfungsi untuk menentukan batas maksimum putaran sumbu (axis) motor servo. Sudut dari sumbu motor servo diatur berdasarkan lebar pulsa yang pada pin kontrol motor servo. Pada bagian luar motor servo terdapat beberapa komponen seperti housing motor servo, konektor kabel, lubang sekrup, dan jangkar. Posisi putaran sumbu (axis) dari motor akan diinformasikan kembali ke rangkaian kontrol yang ada di dalam motor servo. Motor servo mampu bekerja dengan arah putaran searah jarum jam dan berlawanan dengan jarum jam. Arah dan sudut pergerakan rotornya dapat dikendalikan dengan memberikan pengaturan duty cycle sinyal PWM pada bagian pin kontrolnya [4].

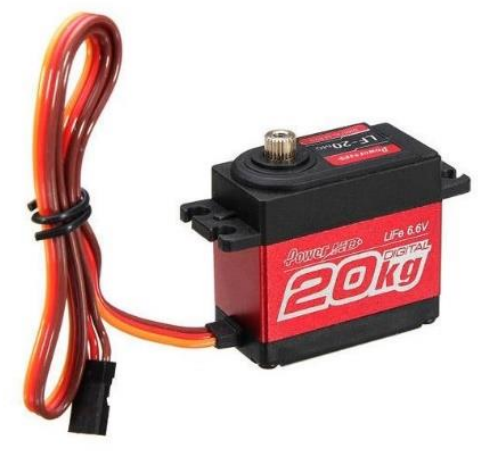

Gambar 3. Motor Servo type LF-20MG [3]

\subsection{SENSOR TIMBANGAN}

Elemen elastik berbentuk beam dengan lubang di tengah. Di dalam lubang direkatkankan strain gauge dibagian yang akan mengalami regangan paling tinggi ketika elemen elastik diberi beban/gaya F. Salah satu sisi elemen elastik dijepitkan dan sisi lainnya diberikan beban. Saat diberi beban, elemen elastik terdeformasi. Deformasi berupa regangan ditangkap oleh strain gauge dan diolah oleh rangkaian Jembatan Wheatstone untuk mendapatkan tegangan output $\mathrm{e} 0 \mathrm{~V}$ yang proporsional dengan beban/ gaya $\mathrm{F}[4]$.

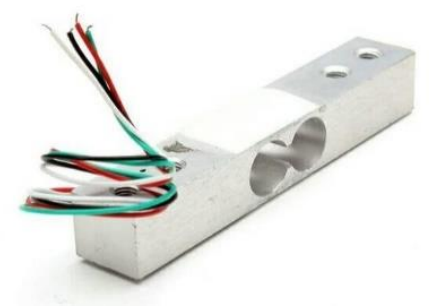

Gambar 4. Load Cell [4]

\subsection{LaOd Cell Module}

HX711 merupakan sebuah komponen terintegrasi dari "AVIA SEMICONDUCTOR" dengan kepresisian 24-bit analog to digital converter (ADC) yang didesain untuk sensor timbangan digital dan aplikasi industrial control yang terkoneksi dengan sensor jembatan atau sensor model jembatan wheatstone. HX711 adalah modul timbangan, yang memiliki prinsip kerja mengkonversi perubahan yang terukur dalam perubahan resistansi dan mengkonversinya ke dalam besaran tegangan melalui rangkaian yang ada [4].

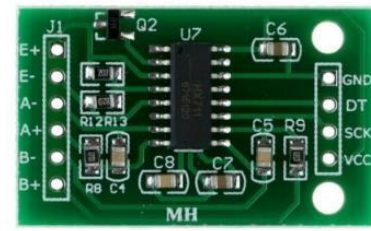

Gambar 5. HX711[4]

\subsection{MESIN PEMBERI PAKAN IKAN OTOMATIS}

Mesin pemberi pakan ikan otomatis dengan ArduinoSmart Feeding Machine System (SFMS) merupakan teknologi baru yang pertama kali diperkenalkan oleh Noor tahun 2012 pada jurnal berjudul "The design and development of automatic fish feeder system using PIC microcontroller". Noor memberikan pembaharuan sistem berupa pengaturan dari secara individual. SFMS saat sering digunakan pada skala. SFMS pada perkembangannya dikendalikan melalui microcontroller[5].

Keuntungan menggunakan mesin pemberi pakan ikan otomatis :

a. Pengaturan pemberian pakan ikan kolam dapat terpantau secara otomatis.

b. Pada skala besar, sistem ini memberikan keuntungan lebih berupa optimalisasi biaya produksi.

c. Manajemen pakan ikan akan lebih mudah dilakukan dengan sedikit orang

d. Mesin pemberi pakan ikan otomatis dapat dikembangkan menjadi sistem yang lebih cerdas, dimana mesin pemberi pakan ikan otomatis dapat diatur melalui internet atau smartphone.

e. Pada tujuan Internet of Things, mesin pemberi pakan ikan otomatis dapat menjadi sistem terpadu dalam meningkatkan produktivitas ternak ikan.

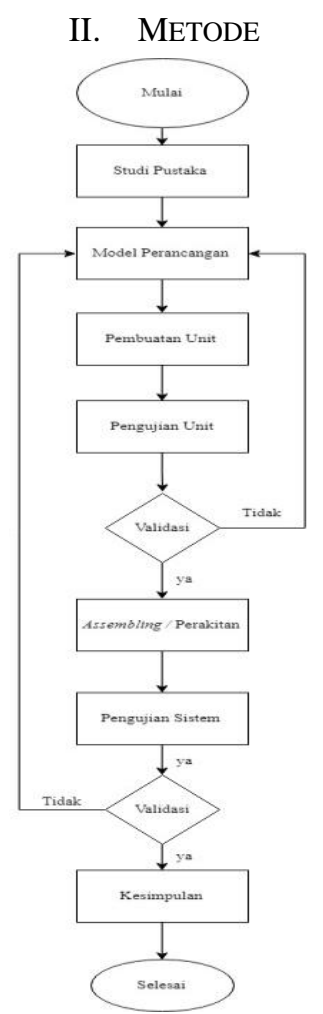

Gambar 6. Flowchart Sistem 


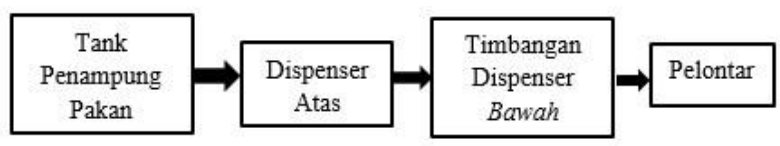

Gambar 7. Blok Diagram Kerja Alat

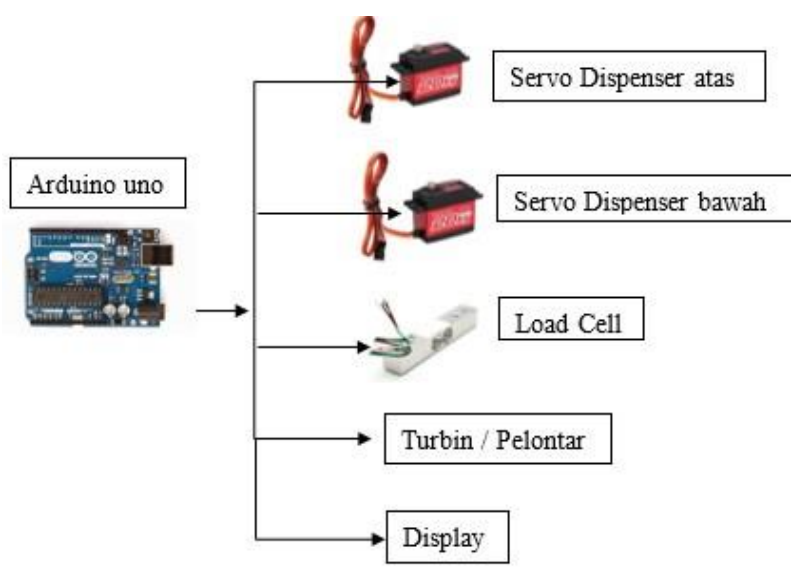

Gambar 8. Arsitektur Rancangan

\section{JENIS PAKAN IKAN YANG DIUJI}

Tabel 1. Ukuran Pakan Yang Diuji

\begin{tabular}{|lcc|} 
No & Jenis Pakan & Ukuran $(\mathbf{m m})$ \\
\hline $\mathbf{1}$ & A & $\mathbf{2}$ \\
\hline 3 & B & 3.5 \\
\hline 4 & C & 5.5 \\
\hline
\end{tabular}

\section{METODE PENGUJIAN}

Pengujian dilakukan dengan cara membedakan jenis pakan terlebih dahulu jenis pakan yang digunakan ada 3 jenis A, B dan C. Kemudian pakan diuji dengan cara pembukaan valve yang telah ditentukan, yaitu bukaan $45^{\circ}$ dan $90^{\circ}$ untuk Pakan A. Bukaan $45^{0}, 90^{0}, 180^{0}$ untuk Pakan B dan C. Untuk pengujian setiap jenis pakan dengan kelipatan $1 / 4 \mathrm{Kg}$ sampai dengan maksimal $3 \mathrm{Kg}$ sebanyak 12 kali pengujian dan yang dicari yaitu pengaruh derajat bukaan valve terhadap flow pakan. Adapun pengujian valve timbangan pada tabung dilakukan dengan cara tiap kelipatan $1 / 4 \mathrm{Kg}$ pakan dilakuakn 10kali pengulangan untuk mengetahui galat yang dihasilkan kemudian mencari ratarata waktu, arus dan tegangan.

Pengujian yang dilakukan yaitu :

1. Pengujian Konsisten

2. Pengujian Akurasi

3. Pengujian Kondisi dan Kerja

4. Pengujian Lontaran

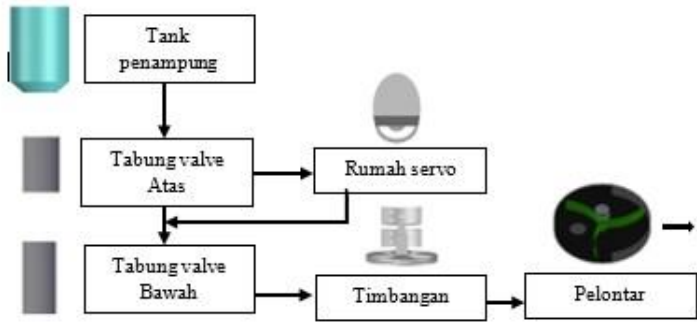

Gambar 9. Blok Diagram Perencanaan
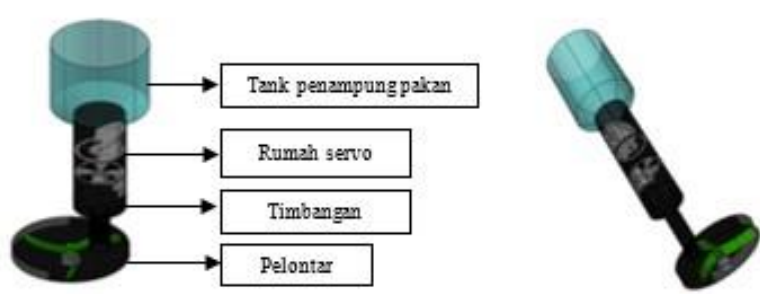

Gambar 10. Rancangan Arsitektur

\section{PEMBAHASAN}

Pada pengujian lontaran, pelontar disimpan pada ketinggian $140 \mathrm{~cm}$ dengan putaran penuh atau $100 \%$ dengan flow pakan 30g/ detik, 50g/ detik dan 70g/detik di setiap pengujiannya menggunakan pakan dengan jenis pakan A, B dan C.

Pada pengujian lontaran, pelontar disimpan pada ketinggian $140 \mathrm{~cm}$ dengan putaran $75 \%$ dengan flow pakan $30 \mathrm{~g} /$ detik, $50 \mathrm{~g} /$ detik dan $70 \mathrm{~g} /$ detik disetiap pengujiannya menggunakan pakan dengan jenis pakan A, B dan C. Pada pengujian lontaran, pelontar disimpan pada ketinggian $140 \mathrm{~cm}$ dengan putaran $50 \%$ dengan flow pakan $30 \mathrm{gr} /$ detik, 50gr/ detik dan 70gr detik di setiap pengujiannya menggunakan pakan dengan jenis pakan A, B dan C. Putaran yang dihasilkan 1092rpm dengan arus 6,81A lontaran pakan didominasi pada jarak $6 \mathrm{~m}$ dengan sudut lontaran $75^{\circ}$ terhitung dari titik $0^{\circ}$ pada lubang lontaran pakan.

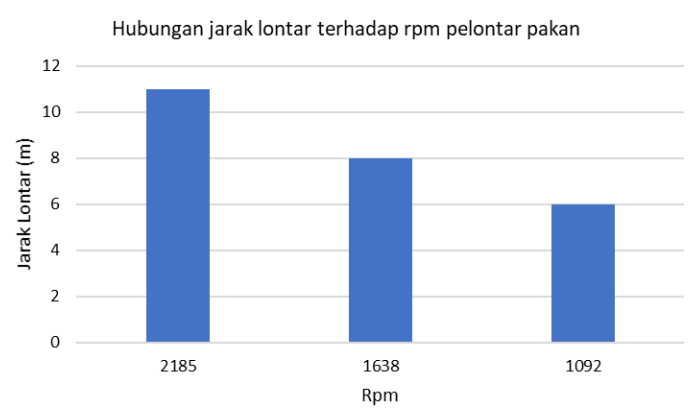

Gambar 11. Hasil uji jarak lontaran pakan dari unit pelontar

Tabel 2. Pengujian Lontaran Pakan dengan PWM

\begin{tabular}{lccc}
\hline Lavel putaran (\%) & Rpm & Arus (A) & $\begin{array}{c}\text { Jarak } \\
\text { lontar (m) }\end{array}$ \\
\hline 100 & 2185 & 16.5 & $11-13$ \\
\hline 75 & 1638 & 11.1 & $8-13$ \\
\hline 50 & 1092 & 6.81 & $6 \mathrm{~m}$ \\
\hline
\end{tabular}


Pada pengujian flow pakan terhadap bukaan $45^{\circ}$ pada paka ukuran A, hanya dilakukan 5 kali percobaan dikarenakan pada bukaan $45^{\circ}$ tidak membuat perubahan yang signifikan apabila dilakukan 12 kali percobaan seperti pada percobaan sebelumnya dengan bukaan yang sama. Pakan ukuran B dilakukan pengujian sebanyak 12 kali percobaan dimulai dengan percobaan dengan bobot pakan $0,25 \mathrm{~kg}$ untuk pengujian selanjutnya dilakukan dengan bobot pakan kelipatan $0,25 \mathrm{~kg}$ per setiap kali percobaan. Pengujian dengan ukuran pakan $\mathrm{C}$ dilakukan 4 kali percobaan karena untuk percobaan pada bobot $1,25 \mathrm{~kg}$ pada bukaan $45^{\circ}$ mengalami kegagalan sistem mekanik dari segi bukaan dan dimensi pakan.

Hasil analisis menyatakan bahwa hasil tidak linier dari segi waktu terhadap bobot pakan, akan tetapi pada dasarnya ketika durasi semakin lama maka arus yang dihasilkan akan semakin menurun dan daya semakin kecil. Dikarenakan beban pada waktu yang singkat akan mempengaruhi kenaikan arus.

Uji sistem lontaran pada bukaan valve 45 derajat

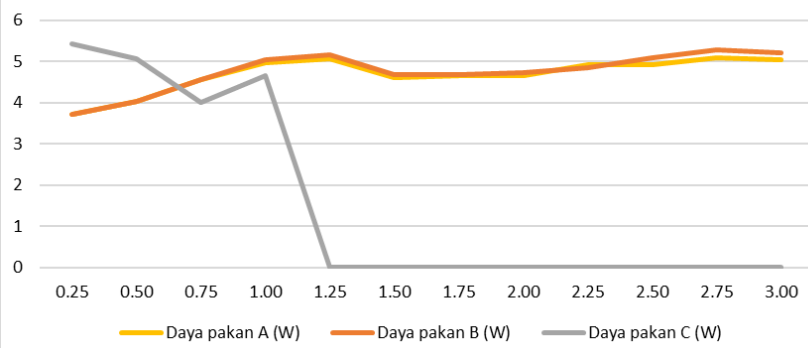

Gambar 12. Uji konsumsi daya pada unit valve pakan dengan bukaan $45^{0}$

Pada Pengujian flow pakan terhadap bukaan $90^{\circ}$ pada paka ukuran A, dilakukan 12 kali percobaan dengan bukaan yang sama. pakan ukuran B dilakukan pengujian sebanyak 12 kali percobaan dimulai dengan percobaan dengan bobot pakan $0,25 \mathrm{~kg}$ untuk pengujian selanjutnya dilakukan dengan bobot pakan kelipatan $0,25 \mathrm{~kg}$ per setiap kali percobaan.

Uji sistem lontaran pada bukaan valve 90 derajat

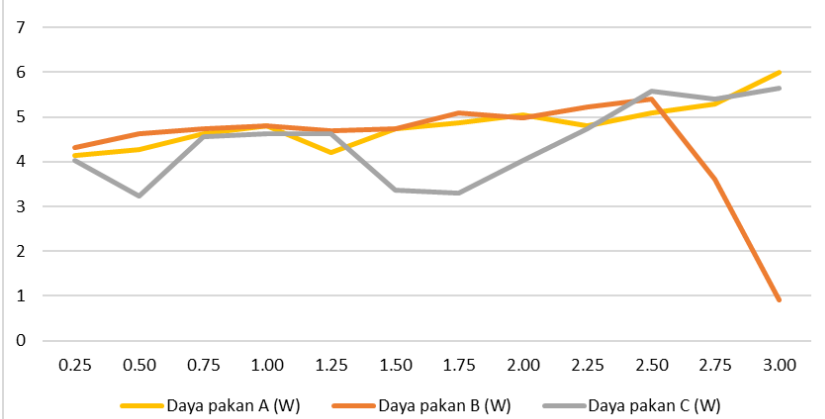

Gambar 13. Uji konsumsi daya pada unit valve pakan dengan bukaan $90^{\circ}$

Pada pengujian flow pakan terhadap bukaan $180^{\circ} \quad 12$ kali percobaan dengan bukaan yang sama akan tetapi dimulai dari jenis pakan B karena untuk pakan dengan ukuran C memiliki dimensi yang besar oleh karena itu pakan terkukur linier. Untuk pakan ukuran B dilakukan pengujian sebanyak 12 kali percobaan dimulai dengan percobaan dengan bobot pakan $0,25 \mathrm{~kg}$ untuk pengujian selanjutnya dilakukan dengan bobot pakan kelipatan $0,25 \mathrm{~kg}$ per setiap kali percobaan.
Pengujian dengan ukuran pakan $\mathrm{C}$ dilakukan 12 kali percobaan dari hasil analisis menyatakan bahwa hasil linier dari segi waktu terhadap bobot pakan.

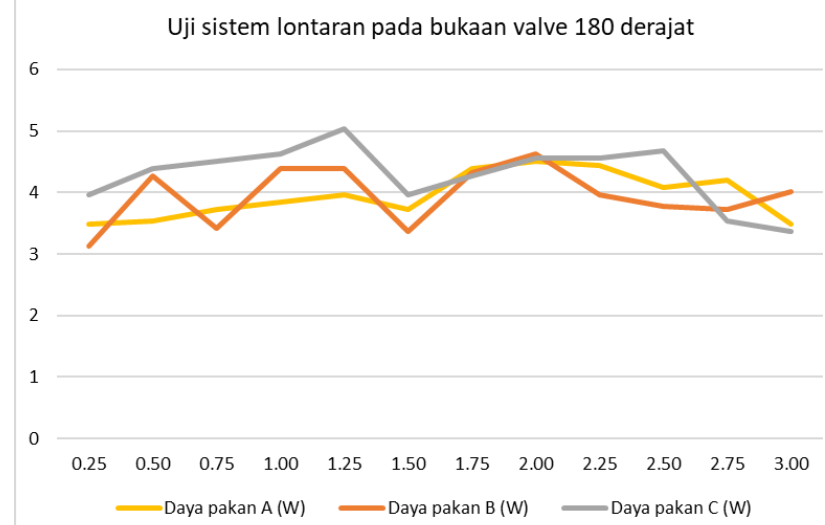

Gambar 14. Uji konsumsi daya pada unit valve pakan dengan bukaan $180^{\circ}$

Tabel 3. Pengujian flow pakan A terhadap pelontar

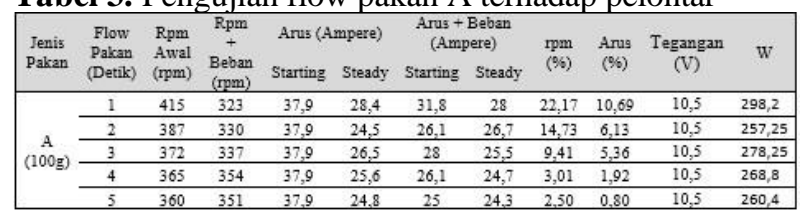

Tabel 4. Pengujian flow pakan B terhadap pelontar

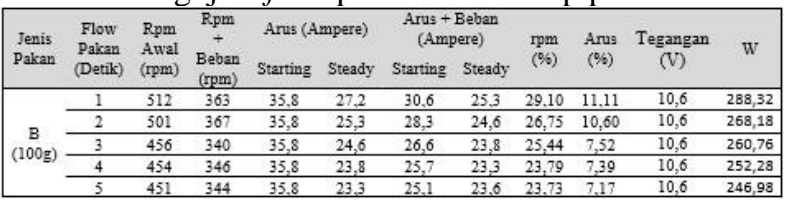

Tabel 5. Pengujian flow pakan C terhadap pelontar

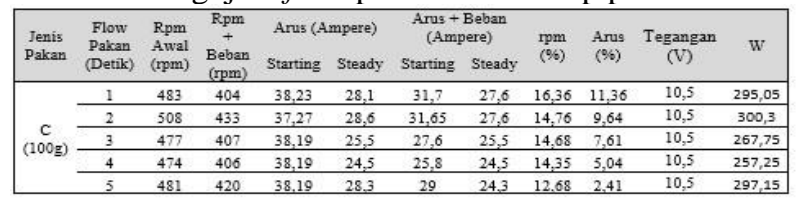

Pada pengujian pelontar dengan pully dilakukan dengan pakan jenis $\mathrm{A}, \mathrm{B}$ dan $\mathrm{C}$ tegangan yang masuk ke motor ratarata sebesar $10,5 \mathrm{~V}$. Cara pengujian pertama-tama menyediakan pakan dengan bobot $100 \mathrm{~g}$ kemudian pakan dituangkan ke pelontar dengan flow pakan $100 \mathrm{~g} /$ detik, $100 \mathrm{~g} / 2$ detik, $100 \mathrm{~g} / 3$ detik, $100 \mathrm{~g} / 4$ detik dan $100 \mathrm{~g} / 5$ detik ke pelontar.

Selanjutnya diamati arus ketika starting dan juga ketika pelontar diberi beban pakan dengan tegangan

$12 \mathrm{~V}$ akan terjadi kenaikan arus saat pelontar diberi beban pakan. Titik jatuh pakan mempengaruhi arus karena beban pakan.

Tabel 6. Pengujian flow pakan A terhadap pelontar

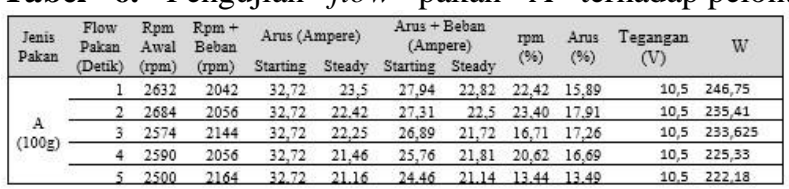


Tabel 7. Pengujian flow pakan B terhadap pelontar

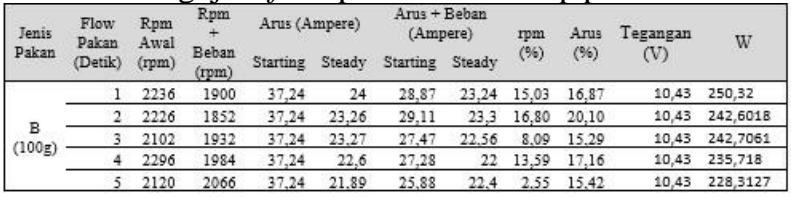

Tabel 8. Pengujian flow pakan C terhadap pelontar

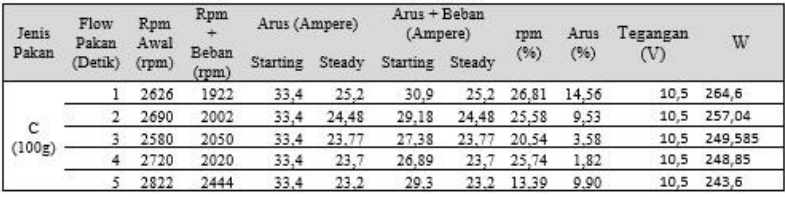

Pada pengujian pelontar dengan pully dilakukan dengan pakan jenis $\mathrm{A}, \mathrm{B}$ dan $\mathrm{C}$ tegangan yang masuk ke motor rata-rata sebesar $10,5 \mathrm{~V}$. Cara pengujian pertama-tama menyediakan pakan dengan bobot $100 \mathrm{~g}$ kemudian pakan dituangkan ke pelontar dengan flow pakan $100 \mathrm{~g} / \mathrm{detik}, 100 \mathrm{~g} / 2$ detik, $100 \mathrm{~g} / 3$ detik, $100 \mathrm{~g} / 4 \mathrm{detik}$ dan $100 \mathrm{~g} / 5$ detik ke pelontar.

Selanjutnya diamati arus ketika starting dan juga ketika pelontar diberi beban pakan dengan tegangan $12 \mathrm{~V}$ akan terjadi kenaikan arus saat pelontar diberi beban pakan. Titik jatuh pakan mempengaruhi arus

karena beban pakan.

\section{KESIMPULAN DAN SARAN}

Perancangan dispenser pakan ikan otomatis dengan sistem hemat energi, menggunakan sistem mekanik bukaan vertikal agar bukaan pada valve dispenser berkerja hanya pada saat sensor timbangan memberikan perintah sesuai dengan sistem.

Pemodelan pada dispenser valve atas diberi sudut $45^{\circ}$ agar pada saat flow pakan jatuh ke sensor timbangan terakurasi oleh titik jatuh pakan, juga untuk meminimalisir galat pengkalibrasian sensor timbangan.

Pelontar dengan kecepatan putaran motor diatas 3000rpm terpasang baling-baling pelontar diturunkan kecepatannya menggunakan sistem mekanik pully 1:2 menjadikan kecepatan putaran motor diatas 2000rpm.

\section{REFERENSI}

[1] Dinas Perikanan Kabupaten Buleleng, "Potensi Usaha Budidaya Ikan Air Tawar," 2018. [Online]. Available:

https://bulelengkab.go.id/detail/artikel/pote

nsi-usaha-budidaya-ikan-air-tawar-41. [Accessed: 06-Aug-2019].

[2] arduino, "Referensi Arduino," 2019. [Online]. Available: https://www.arduino.cc/reference/en/. [Accessed: 06-Aug-2019].

[3] Power HD, "Power HD - HuiDa RC International LimitedLF-20MG." [Online]. Available: http://www.chd.hk/Product_Detail.aspx?id =142. [Accessed: 06-Aug-2019].

[4] R. Debriand, M. Doloksaribu, and I.

Damanik, "Rancang Bangun Timbangan Load Cell Tipe S Design of Weight Sensor Load Cell Type S," vol. 40, no. 2010, 2018.

[5] N. Hiron and A. Andang, "Wireless communication with batching method based on Xbee-PRO S2B module for sensing of wind speed," 2017. 